\title{
The Scale of Entrepreneurship in Middle Eastern History: Inhibitive Roles of Islamic Institutions
}

\author{
Timur Kuran
}

Department of Economics, Duke University, 213 Social Sciences Building, Box 90097, Durham, NC 27708, USA — t.kuran@duke.edu - (919) 660-1872

\begin{abstract}
The historical record belies the claim that Islam per se has impeded entrepreneurship by inculcating conformism and fatalism. By the same token, the diametrically opposed view that Islam offers institutions necessarily supportive of entrepreneurship flies in the face of the historical transformations associated with economic modernization. Islamic institutions that served innovators well in the medieval global economy became dysfunctional as the world made the transition from personal to impersonal exchange. The key problem is that Islamic law failed to stimulate the development of organizational forms conducive to pooling and managing resources on a large scale.
\end{abstract}




\section{Introduction}

Ever since the Middle East slipped into a state of underdevelopment, lack of creativity, excessive risk aversion, and hostility to innovation have been among the factors viewed as causes of its economic shortcomings. Certain observers have linked such attitudes to Islam, the region's main religion. "Islam inculcates a belief in predestination, commonly referred to as fatalism," proposes Raphael Patai. ${ }^{1}$ According to another writer, Yusif Sayigh, the conformism and immobility of Arab societies afflicts even religious minorities and foreigners "whose cultures contain enterprise-generating forces." He explains: "Once minority groups succumb to the inhibitions of the Arab environment through social acclimatization, they lose their distinctive entrepreneurial role." 2 Bernard Lewis has been promoting a variant of this view, which stresses the closing of the Muslim mind between the ninth and eleventh centuries. This transformation, he says, has had adverse effects on enterprise, experimentation, and creativity in a wide array of contexts, including production and commerce. ${ }^{3}$

The thesis that Islam discourages entrepreneurship has hardly gone unchallenged. Leading Muslim reformers of the nineteenth century believed that it confuses perverted forms of Islam, which counsel passive resignation to the flow of events, with authentic Islam, which holds the individual responsible for his acts, including his failures, and requires the active use of God-given talents. A vocal exponent of this distinction was Jamal al-Din al-Afghani (1839-97), who had to explain why, if Islam promotes hard work, risk taking and innovation, the strongest countries of his time were predominantly Christian. Christians are strong because they are not really Christian, he answered. The Church developed in the Roman Empire, absorbing its pagan beliefs and virtues; later, its role diminished through secularization. As for Muslims, they are weak because they are not really Muslim. What they preach and practice, al-Afghani held, is Islam only in name. $^{4}$

Islamism, which emerged through the pioneering works of Sayyid Abul-Ala Mawdudi (1903-79), Sayyid Qutb (1906-66), and Muhammad Baqir al-Sadr (1931-80),

\footnotetext{
${ }^{1}$ Patai (1983), The Arab Mind, p. 310.

${ }^{2}$ Sayigh (1958), "Toward a Theory of Entrepreneurship for the Arab East," p. 310.

${ }^{3}$ Lewis (2002), What Went Wrong?, especially chap. 7.

${ }^{4}$ Hourani (1983), Arabic Thought in the Liberal Age, 1798-1839, pp. 128-29.
} 
by and large shares al-Afghani's view that Islam encourages vigorous entrepreneurship. It promotes creative experimentation, Islamists hold, at least in regard to science, technology, and economics. At a time when one could graduate from a top-ranked American economics department without exposure to the concept of entrepreneurship, contributors to Islamic economics, a doctrine ostensibly based on the fundamental sources of Islam, was highlighting Islamic institutions designed to stimulate entrepreneurship. ${ }^{5}$ Islamic banks, the most salient modern achievement of Islamic economics, are meant to operate as suppliers of venture capital. In principle, it finances promising entrepreneurs without regard to their ability to post collateral, for a share of their profits. ${ }^{6}$ Islamic economics texts routinely cite Quranic passages interpreted as encouraging entrepreneurship, such as the following: "When the prayers are ended, disperse and go in quest of Allah's bounty" (62:10). The same texts are replete also with pro-entrepreneurial statements attributed to Muhammad and his close companions. On Judgment Day, Muhammad is reputed to have said, faithful and trustworthy merchants will sit with prophets and martyrs. ${ }^{7}$

The uninitiated may wonder whether these assorted commentators are referring to the same region or religion. In fact, each draws a caricature. Islamic economics effectively equates a selective reading of Islamic doctrines with the actual practices of Muslims, failing to recognize the existence, let alone explain the persistence, of Islamic institutions inimical to economic creativity. One contributor presents Islamic banking, which emerged in the 1970s, as testament to the adaptability of Islamic law, neglecting to address why under Islamic law the institutions of private finance essentially stagnated for close to a millennium. ${ }^{8}$ Al-Afghani characterizes as corruption the deficiencies of Muslim practices, without explaining why "authentic Islam" proved corruptible and allowed inefficiencies. For their part, observers who consider Islam fatalistic and

\footnotetext{
${ }^{5}$ Mannan (1970), Islamic Economics, offers an influential introduction to Islamic economics. Extensive treatments of entrepreneurship are found, among other sources, in Siddiqi (1979), The Economic Enterprise in Islam, chap. 2; and Sadeq (1990), Economic Development in Islam, pp. 24-29. For a critique of Islamic economics and an account of its history, see Kuran (2004), Islam and Mammon, chaps. 1-5.

${ }^{6}$ In reality most Islamic banks operate like ordinary commercial banks; their Islamic features are mostly cosmetic. See Kuran (2004), Islam and Mammon, pp. 7-19, 43-49; and El-Gamal (2006), Islamic Finance, pp. 7-25.

${ }^{7}$ Sadeq (1990), Economic Development in Islam, pp. 25, 36.

${ }^{8}$ Ahmed (2006), "Islamic Law, Adaptability and Financial Development."
} 
conservative overlook that for much of Islamic history, including the half-millennium that followed the period that Lewis considers a turning point, the Middle East was considered prosperous. The anti-Islamic diatribes of medieval and even early modern Europe fault Islam for many things, but they do not treat it as a source economic backwardness. Quite the contrary: sworn enemies of Islam lauded the prosperity of Muslim-governed lands. ${ }^{9}$ Visitors of the sixteenth century did not consider the Middle East lacking in what we now call entrepreneurship.

With the partial exception of Islamic economics, these strands of thought overlook that decisions to innovate depend on institutions. No matter how motivated people are to experiment, take chances, or explore the unknown, if they cannot raise the necessary capital, or entrepreneurial rewards are vulnerable to predation, they will turn their energies elsewhere. To an outsider, they will seem fatalistic or wedded to tradition. They will appear to lack the motivation to improve the workings of their society, solve problems, and raise living standards. Attitudes are by no means irrelevant to economic success. Yet, by themselves such traits as fatalism and conservatism do not explain the political, economic, and social underdevelopment of today's Arabs, Middle Easterners, or Muslims. Insofar as the traits are ascribed to Islamic teachings, there is the further problem that Islam, like other great religions, has a rich and varied heritage capable of supporting a plethora of causes and lifestyles. If anti-entrepreneurial attitudes are dominant, one must explain why one particular interpretation of Islam has prevailed.

To its credit, Islamic economics recognizes that the institutional nexus affects entrepreneurial incentives. Yet, what it offers as the ideal set of institutions is an oversimplified interpretation of classical Islamic law, which took shape between the seventh and tenth centuries. It assumes, in effect, that the efficiency of institutions is invariant to context. ${ }^{10}$ Accounts of Islamic history that point to attitudinal changes around the tenth century share this characteristic: in failing to pay attention to the infrastructure of exchange, they effectively treat it as irrelevant to entrepreneurial performance.

In fact, the supply of entrepreneurship depends on the suitability of the prevailing institutions to the challenges at hand. This means that it may vary with changes in the

\footnotetext{
${ }^{9}$ Rodinson (1987), Europe and the Mystique of Islam, especially pp. 18-23.

${ }^{10}$ For detailed critiques in this vein, see Kuran (2004), Islam and Mammon; and El-Gamal (2006), Islamic Finance.
} 
global economic environment. As I will show, Middle Eastern institutions well suited to personal exchange - the norm in the medieval global economy-became a source of retardation with the transition to impersonal exchange. Though continuing to support small-scale entrepreneurship, they inhibited larger-scale entrepreneurship. Removing obstacles to entrepreneurship is itself among the tasks of entrepreneurs. But certain obstacles are harder to overcome than others. A satisfactory account of Middle Eastern entrepreneurial history, or specifically of links between Islam and Middle Eastern entrepreneurship, must make sense not only of the observed entrepreneurial record, but also of the associated institutional history.

\section{Entrepreneurship and Its Dependence on History}

Entrepreneurship is a concept used often used imprecisely. Here it refers to the activities of people who are extraordinarily alert to opportunities for gain and unusually eager to seek ways to exploit them. Like everyone else, entrepreneurs receive far more information than their minds can process. Unlike most others, they have the insight and foresight to sense what bits of information point to opportunities for gain. Their responses dampen disequilibria, as Friedrich Hayek and Israel Kirzner emphasized. ${ }^{11}$ They also lessen inefficiencies, as Harvey Leibenstein was inclined to stress. ${ }^{12}$ As a byproduct, they generate new disequilibria and inefficiencies, creating, as Joseph Schumpeter argued, exploitable opportunities for others. ${ }^{13}$

With respect to an economy subject to natural shocks, and situated in a dynamic global economy, these varied insights correspond to facets of a single process of decentralized transformation. Fusing them into a single theory of entrepreneurship, as Mark Casson has attempted, makes entrepreneurs appear at once as initiators, exploiters, and managers of change. ${ }^{14}$ They create new markets, but also enhance their productivity in existing ones. They generate new forms of organization, find novel ways to deploy the new forms, and undertake refinements.

\footnotetext{
${ }^{11}$ Hayek (1937), “Economics and Knowledge,"; Kirzner (1979), Perception, Opportunity, and Profit.

${ }^{12}$ Leibenstein (1968), "Entrepreneurship and Development."

${ }^{13}$ Schumpeter (1934), The Theory of Economic Development.

${ }^{14}$ Casson (2003), The Entrepreneur.
} 
This integrative view of entrepreneurship implies that it can feed on itself. With every active entrepreneur unwittingly creating opportunities for others, innovations can stimulate further innovations. A society that has experienced many recent innovations will feature disequilibria in many markets, presenting myriads of opportunities to alert people. Their entrepreneurial activities will then generate new dislocations, presenting opportunities to a fresh set of entrepreneurs. By the same token, if entrepreneurship is somehow deficient, the deficiency need not be self-correcting. Precisely because of the paucity of entrepreneurship, exploitable disequilibria will be scarce, and the condition of limited entrepreneurship will perpetuate itself. A social system that has been stagnant will experience relatively few dislocations. Hence, its entrepreneurs will find few opportunities to put their talents to use. In brief, the supply of entrepreneurship is dependent on history. A society can stagnate because it was stagnant in the past. It can find itself trapped in a lethargic state characterized by low entrepreneurship, not because it lacks risk takers capable of innovation but simply because of its entrepreneurial history.

The social unit experiencing persistently low entrepreneurship need not be as large as an entire civilization, or even a nation. It could be an economic sector or geographic region. One sector may appear structurally stagnant, and its members lethargic, conservative, and fatalistic, even as another displays creativity and vigor. The contrast will be compounded insofar as entrepreneurs are mobile. In search of higher returns to their talents, they will flock to the relatively dynamic sector.

Scholars who characterize the Middle East or the broader Islamic world as deficient in entrepreneurship usually have in mind its commercial sectors. This emphasis has a sound empirical basis. Historically, the state sector displayed considerable flexibility in domains critical to its own survival. For instance, methods of taxation changed repeatedly in response to new conditions. ${ }^{15}$ By contrast, neither Islamic contract law nor the contractual practices of merchants, producers, and investors changed significantly between the tenth and seventeenth centuries. ${ }^{16}$ This institutional stagnation

\footnotetext{
${ }^{15}$ Løkkegaard (1950), Islamic Taxation in the Classical Period, with Special Reference to Circumstances in Iraq; Darling (1996), Revenue-Raising and Legitimacy; Coşgel (2005), "Efficiency and Continuity in Public Finance."

${ }^{16}$ Goitein (1967), A Mediterranean Society, 1, offers evidence on contractual forms used in tenth-century Egypt. My own data set of commercial cases handled by Istanbul's Islamic courts between 1550 and 1692 shows that the contractual forms did not differ in any fundamental way. Reviewed court registers (defters):
} 
went hand-in-hand, we shall see, with a slip in the relative global significance of entrepreneurial feats by Middle Eastern businessmen. The challenge ahead is to identify the sources of this relative decline. As a prelude to this inquiry, it is worth reminding ourselves that by medieval global standards the Middle East was not deficient in entrepreneurship.

\section{Entrepreneurial Activity in the Medieval Middle East}

The emergence and spread of Islam in the early seventh century CE, like the development of other great religions, involved entrepreneurial acts of immense ingenuity. Muhammad displayed remarkable social, political, economic, and military ingenuity in securing the earliest conversions, moving with his co-religionists from Mecca to Medina to establish a rudimentary state, and then defeating his pagan opposition by taking control of the region's commercial arteries. Over the next few centuries the development of Islamic norms, standards, rules, laws, practices, organizations, belief systems, and reward mechanisms entailed, likewise, a highly creative synthesis based on the appropriation, but also the refinement and modification, of pre-Islamic institutions.

Of particular interest here are institutions designed to facilitate entrepreneurship. Entrepreneurs commonly lack the resources to carry out their ambitions. To succeed, they depend on the capital and labor of others. Classical Islamic law harbors a law of contracts that offers entrepreneurs various contractual templates, each suitable to a distinct range of objectives. This law provided peoples all across the Islamic world, which by the eighth century stretched from the Atlantic Ocean to the shores of China, an essentially uniform legal system enforceable wherever Muslims ruled.

The indebtedness of Islamic contract law to other civilizations is a matter of controversy, as are its influences on the institutional evolution of Mediterranean Europe. What is settled is that around the tenth century it was at least as advanced as its analogues prevalent elsewhere. Not surprisingly, at the time Islam was still spreading to far corners of the world, sometimes through the sword, but also through the establishment of mercantile colonies operating under Islamic law. It was merchants who carried Islam to

Galata 41, 42, 124, 130, 131, 137, 138, 145, 151; Istanbul 1, 2, 8, 9, 15, 16, 22, 23; Rumeli 21, 22, 26, 27 , $33,34,40,41$. 
many parts of East Africa, India, China, and, later, Indonesia. Their trading posts attracted diverse professionals. In addition to privileged access to their services, the incentives for converting to Islam included acceptance into lucrative Muslim trading networks, preferential treatment in Islamic courts, eligibility for high administrative positions, and sometimes also lower taxation.

The commercial missions that contributed to Islam's expansion generally entailed forays into the unknown. Prior to the emergence of Muslim-Chinese colonies, boarding a ship or joining a caravan headed to China required courage as well as a taste for adventure. Ordinarily an individual who undertook such a voyage sought outside financing under Islamic contract law. Securing the necessary financing was itself a challenge requiring creativity. The missions also required collective action, to achieve both security in numbers and bargaining power in negotiations. Although information on Islam's early commercial expansions is scant, we know that when a ship carrying Middle Easterners arrived in a foreign land, representatives of its passengers negotiated with the ruler's side over trading privileges and settlement rights.

The voyages that carried Middle Eastern merchants to uncharted foreign lands often resulted in the opening of new markets. ${ }^{17}$ The early waves of Middle Eastern settlers in East Africa introduced new commodities into the continent. Where commercially less advanced societies were involved, the process of market opening also required the diffusion of certain Middle Eastern institutions. Thus, in connecting parts of tropical Africa with global markets, Muslim merchants carried commercial regulations into places without written laws. They also introduced arithmetic, which simplified accounting, and metal coins, which facilitated payments and wealth accumulation. Further, they spread Arabic as a commercial lingua franca-a facilitator of communication, and thus exchange and cooperation, among areas previously segregated by linguistic differences. Each such facet of Islam's commercial expansion involved one or more forms of entrepreneurship. Transplanting institutions across regions, organizing commercial trips with highly uncertain outcomes, building commercial links with

\footnotetext{
${ }^{17}$ Ashtor (1976), A Social and Economic History of the Near East in the Middle Ages, chap. 3; AbuLughod (1989), Before European Hegemony, chap. 8; Chaudhuri (1985), Trade and Civilisation in the Indian Ocean, chap. 2.
} 
unknown territories, establishing new markets, and introducing people to new commodities are entrepreneurial activities par excellence.

By the standards of the time, the commercial expansion in question represents an immense accomplishment. Numerous giant commercial centers of the age owed their prominence to Middle Eastern settlers. They include Mombasa and Mogadishu in Africa, and Calicut, Malacca, and Canton in Asia. In many such centers Islam became the dominant religion, although their Middle Eastern settlers also included Christians, Jews, and Zoroastrians. The Middle Easterners who moved to certain faraway places formed huge communities. When bandits captured Canton in 878 and slaughtered its local population, the victims included 120,000 Middle Eastern immigrants, mostly Muslims. ${ }^{18}$

The establishment of Muslim-dominated trading centers in tropical Africa, the Asian sub-continent, and East Asia is all the more remarkable considering that the natives of these regions did not build trading colonies of their own, or spread their commercial institutions, in the Middle East. The asymmetry has been attributed to the cyclical rhythms of the monsoon winds and seasonal crop patterns. But the peoples of other regions, for instance the Chinese, could have overcome any climactic disadvantages precisely by establishing trading colonies in the Middle East, along with appropriate institutions. With respect to China, another view, often appended to the climactic argument, is that its emperors did not need foreign trade, as its internal economy provided an adequate tax base. ${ }^{19}$ Putting aside the empirical difficulties with treating the ambitions of Chinese rulers as bounded, one must ask why so few Chinese merchants sought to exploit commercial opportunities in the Middle East, as they did in Southeast Asia. The reason probably lies in the first mover advantage of the Middle Easterners who came to dominate various trade routes. Where Islam had already achieved a significant presence, the local population would have had no particular reason to welcome settlers, unless they had superior commercial institutions. The institutions of the Chinese were not noticeably superior.

If Middle Easterners of the first few Islamic centuries established institutions favorable to the sort of entrepreneurship that fueled commercial expansion under early

\footnotetext{
${ }^{18}$ Hourani (1995), Arab Seafaring, pp. 61-79; and Chaudhuri (1985), Trade and Civilisation, chap. 2.

${ }^{19}$ Chaudhuri (1985), Trade and Civilisation, pp. 21-29, 188.
} 
Islamic law, a major reason is that the Muslim jurists who incorporated them into Islamic law, and refined them repeatedly, were themselves businessmen. In the Arab heartland of Islam, during the ninth and tenth centuries 75 percent of all religious scholars ('ulama '), whose ranks included all jurists, earned a living primarily from business. Although most were sedentary artisans or producers, many participated in commerce as investors or, less commonly, as traveling merchants. ${ }^{20}$ Born into a merchant-dominated tribe, Muhammad himself was a merchant by profession. Such factors did not guarantee that Islam would promote institutions supportive of entrepreneurship. However, they ensured that during its formative period people familiar with entrepreneurial needs, even entrepreneurs themselves, held influential positions.

\section{The Onset of Stagnation in Entrepreneurial Effectiveness}

The early centuries of Islamic history stand out as a time of particularly remarkable commercial feats by Middle Easterners. Subsequently, the global significance of their commercial accomplishments declined noticeably. In the sixteenth century, some Arabs still went to India; few traveled as far as China. By the eighteenth century even the region's spice trade with India, once a source of fabled wealth, had lost its importance. Spice caravans between the Indian Ocean and the Mediterranean became a spectacle of the past because Europeans developed and monopolized a cheaper route around the Cape. Middle Easterners continued to dominate certain trade routes in Africa a while longer. However, in the nineteenth century Europeans made inroads even into its Muslimdominated regions once commercially tied to the Middle East.

By the middle of the second millennium, Middle Easterners were playing at best a secondary role in the expansion of global commerce. The global explorations and conquests associated with names such as Vasco da Gama, Christopher Columbus, Ferdinand Magellan, and Hernán Cortés were planned, financed, and executed with only peripheral Middle Eastern involvement. Likewise, in the half-millennium preceding the Industrial Revolution the myriads of institutional innovations that laid the infrastructure of today's modern economy came primarily from western merchants, financiers,

\footnotetext{
${ }^{20}$ Cohen (1970), "The Economic Background and the Secular occupations of Muslim Jurisprudents and Traditionists in the Classical Period of Islam (Until the Middle of the Eleventh Century)," table C-1.
} 
statesmen, and other professionals. In contrast to the medieval period, their Middle Eastern counterparts played no leading role in the early modern phase of the long process of institutional development that led to industrialization.

To be sure, even after the development of the global marketplace came to be spearheaded by westerners, every generation of merchants, financiers, and producers included unusually innovative people. Ismail Abu Taqiyya, an Egyptian merchant active in Cairo between 1580 and 1625, offers a shining example. He was born at a time when the use of coffee as a beverage was spreading across the Middle East through Sufis, who drank it in order to stay awake during nocturnal worship services. Puritanical religious scholars found it objectionable, formally on the ground that it causes intoxicationsinful, in their view - but in all likelihood also because of its association with a liberal interpretation of Islam. Nevertheless, the consumption of coffee spread among the general population, largely through coffeehouses. Rulers had a motive of their own for fanning anti-coffee opposition and persecuting violators - even, in some cases, as they themselves acquired a taste for fine coffee. Political activity was integral to the social life of coffee houses, which posed a threat to public order. ${ }^{21}$

In this environment, Abu Taqiyya, along with various partners, started importing coffee to Egypt from Mocha, Yemen. Anticipating Starbucks by several centuries, he also promoted coffee consumption by building scores of coffeehouses. If the profit opportunities were great, so were the risks. For one thing, mobs had destroyed coffeehouses. For another, future demand was dependent on the social and political climate, both uncertain. Abu Taqiyya exhibited an equally impressive entrepreneurial spirit in trying to revive Egypt's sugar industry. Sensing a potential for dramatic market expansion and corresponding price increases, he financed the planting of sugarcane, established refineries, and sold the output both domestically and in the broader Mediterranean market. ${ }^{22}$

Other examples could be given, from Abu Taqiyya's time or later, of Middle Eastern merchants who adapted to emerging market opportunities and took shrewd initiatives to improve products or create new markets. In the seventeenth century an

\footnotetext{
${ }^{21}$ Hattox (1985), Coffee and Coffeehouses, chaps. 1-3, 7.

${ }^{22}$ Hanna (1998), Making Big Money in 1600, pp. 78-95.
} 
Armenian network based in New Julfa, Iran, managed to link markets as far apart as Venice, Russia, India, and China. ${ }^{23}$ Meanwhile, faced with a flood of fine Indian fabrics, Iranians, Turks, and other groups responded by developing and marketing a wide range of substitutes, using dyes from various places, including India itself. ${ }^{24}$ But most of their contemporaries in the world of business followed well-beaten paths. With few exceptions, accounts of commercial life in particular cities and times describe routine business activities. $^{25}$ The merchants who left traces of their careers were less ambitious and less creative.

\section{The Scale and Longevity of Middle Eastern Enterprises}

We will return to the typical pattern on the eve of the Industrial Revolution. Yet Abu Taqiyya's colorful career affords additional insights into entrepreneurial capacity of his region. His accomplishments went beyond entrepreneurial successes in the coffee and sugar markets. However, just as Sherlock Holmes solved a crime by noticing that a dog did not bark, we can learn also from identifying what he did not achieve.

Abu Taqiyya's biographer based her study entirely on several hundreds of court cases in which he appeared as a litigant or witness. She did not have access to financial ledgers, order books, by-laws of his companies, minutes of his strategy sessions with partners, or even his occasional correspondence. These are all the sorts of sources used by historians of the English Levant Company (1583-1825), which operated in the Eastern Mediterranean. ${ }^{26}$ Like the overseas trading companies of the English and other north Europeans, certain Italian companies of earlier centuries left elaborate archives. Surviving financial statements of the Florence-based Medici enterprise (1397-1494) are sufficiently rich and systematic that modern scholars use them to reconstruct its business practices. $^{27}$ In principle, the lack of a private Abu Taqiyya archive could reflect a chance event such as a fire or flood. In fact, it fits a general pattern. Few private commercial

\footnotetext{
${ }^{23}$ Curtin (1984), Cross-Cultural Trade in World History, chap. 9; McCabe (1999), The Shah's Silk for Europe's Silver, chaps. 4, 8-9; and Aghassian and Kévonian (1999), "The Armenian Merchant Network."

${ }^{24}$ Veinstein (1999), "Commercial Relations between India and the Ottoman Empire (Late Fifteenth to Late Eighteenth Centuries)".

${ }^{25}$ See, for instance, Marcus (1989), The Middle East on the Eve of Modernity; and Abdullah (2001), Merchants, Mamluks, and Murder, both on the $18^{\text {th }}$ century.

${ }^{26}$ Wood (1935), A History of the Levant Company.

${ }^{27}$ De Roover (1963), The Rise and Decline of the Medici Bank, 1397-1494.
} 
records of the region have survived from before the nineteenth century. In a 262-page book devoted to historical sources on the Ottoman Empire, to which Egypt belonged in Abu Taqiyya's days, a distinguished historian devotes less than a page to "private archives." ${ }^{28}$ A basic reason is that few private archives were formed in the first place, let alone maintained for generations. ${ }^{29}$

It absorbs resources to save, classify, and preserve documents. Hence, a merchant will go to the trouble only insofar as the expected benefits are sufficiently large. If record keeping is an essential activity of modern firms, this is because they have long lives, enter into long-term contracts with many individuals, and face lawsuits requiring the consultation of agreements made in the distant past. Shareholders may claim rights based on founding documents registered, literally, centuries earlier. It is no coincidence, therefore, that business historians of Italy and England have access to the records of large enterprises that lasted for many generations. The Medicis and the Levant Company left orderly records because their expected longevity and the complexity of their activities justified the costs of forming an archive.

In his career that spanned half a century, Abu Taqiyya operated through myriads of independent partnerships involving geographically dispersed people. Each partnership was based on a separate contract designed for a narrowly defined purpose, such as financing a farmer's sugarcane planting for one season, or transporting a load of coffee beans from Mocha to Alexandria, or operating a coffeehouse in Damiat. These partnerships pooled limited resources and usually they were also short-lived. As such, none presented a need for indefinite record keeping. It is telling that Abu Taqiyya's conglomerate did not outlast him. After his death, some of his associates took over certain components of his conglomerate. Although we do not know the fate of his coffeehouses, many of them probably lived on under different owners and new financial arrangements. But he took with him a web of connections formed over several decades, and no person or organization inherited his region-wide commercial reputation. His commercial capital, too, got dissipated. His heirs did not maintain the conglomerate, to

\footnotetext{
${ }^{28}$ Faroqhi (1999), Approaching Ottoman History, p. 58.

${ }^{29}$ Faroqhi attributes the paucity of Middle Eastern private archives to "wars and civil wars." But western Europe, too, endured destructive political instability, which suggests that a more fundamental factor lies in interregional differences in incentives to maintain records.
} 
say nothing of enlarging it. Therein lies the fundamental reason why his biographer found no Abu Taqiyya archive. If he anticipated his conglomerate's demise after his death, he would have felt no need to keep orderly records.

A basic motive for record keeping is indeed to assist later generations of owners and managers. Yet the Islamic inheritance system diminished the probability of preserving a successful Middle Eastern enterprise. By pre-modern standards the Islamic inheritance system is highly egalitarian. It mandates individual shares for all members of the nuclear family, male and female, and in certain circumstances also for the decedent's more distant relatives. For all its distributional advantages, it led, then, to the fragmentation of successful enterprises. In principle, one could recombine the shares of a deceased businessman's capital. However, ordinarily it took just one or two financially strapped or recalcitrant heirs to block that outcome. The problem was particularly acute for highly successful businessmen, because they tended to have more children, often from multiple wives. Abu Taqiyya's heirs consisted of eleven surviving children and four surviving wives. Although a few of his inheritors tried to consolidate their shares of the estate, within a decade family squabbles, illnesses, and additional deaths took their toll. ${ }^{30}$

Another unintended effect of the Islamic inheritance system was a reduction in the scale and expected longevity of commercial enterprises. Merchants, producers, and investors minimized the probability of having to deal with the heirs of their partners by forming small and ephemeral partnerships. In the process, they also minimized the expected costs of untimely liquidations. ${ }^{31}$ Like so many other successful businessmen of his time, Abu Taqiyya operated through a plethora of partnerships, all mutually independent from a legal standpoint, and each claiming a minute slice of his capital, usually for at most a year or two at a time.

The absence of an Abu Taqiyya archive is symptomatic, then, of a fundamental characteristic of the pre-modern Middle Eastern economy: its dependence on atomistic and generally ephemeral commercial enterprises. If Abu Taqiyya did not establish a formal conglomerate that his descendants could maintain, and thus had no need for elaborate record keeping, a basic reason is that the prevailing commercial institutions of

\footnotetext{
${ }^{30}$ Hanna (1998), Making Big Money in 1600, pp. 161-64.

${ }^{31}$ Kuran (2003), “The Islamic Commercial Crisis," pp. 414-46.
} 
his region made it optimal to work through simple, small, and short-lived private enterprises.

\section{Absence of the Corporation}

The identified obstacles to forming large and durable partnerships under Islamic law do not fully explain why Abu Taqiyya's conglomerate did not outlast him. Institutional limitations are not necessarily insurmountable. Abu Taqiyya might have overcome the limitations of Islamic contract law through an organizational form akin to the business corporation - an enterprise that enjoys legal personality, is capable of a perpetual existence, and allows the transfer of its shares. Had he amalgamated his activities into a corporation, his conglomerate would have had an existence apart from his own. Moreover, his descendants wishing to convert his estate into cash could have transferred equity to others without necessarily endangering the conglomerate itself. Shares of the corporation could have been passed on across generations, with the enterprise living on under a changing membership.

However, Islamic law recognizes only flesh-and-blood persons; it lacks a concept of legal personhood. ${ }^{32}$ This stood as an immense obstacle to introducing the corporation into the Middle East. Abu Taqiyya would have had to reform the judicial system, in addition, of course, to convincing his partners to operate within a radically new business structure. Such mega-innovations are rare in any field. When the Levant Company obtained its corporate charter, it was at the forefront of an unfolding commercial transformation. But its institutional leap was far smaller than the one that Abu Taqiyya would have had to make. Outside of business, the corporate form had seen use in western Europe for more than half a millennium. England's Levant Company did not have to invent legal personhood, or work out its applications from scratch, or deal with judges unfamiliar with the concept.

Had Abu Taqiyya lived in the twenty-first century, he could have established a holding company to rival such enterprises as Orascom Telecom and EFG-Hermes, each traded on both the Cairo and Alexandria Stock Exchange and the London Stock Exchange. Today's leading Egyptian companies use organizational forms inconceivable

\footnotetext{
${ }^{32}$ Kuran (2005b), “The Absence of the Corporation in Islamic Law.”
} 
in Abu Taqiyya's milieu. They also benefit from economic institutions unknown to him, such as secondary share markets, banks, and a business press, to name a few. Egypt's present economic institutions, like those of the wider Middle East, are based on farreaching reforms, launched in waves from the mid-nineteenth century onward. Successive reforms narrowed the jurisdiction of Islamic courts and introduced new legal norms based, in part, on foreign models. By no means is the Egyptian economy of the early twenty-first century a model of efficiency. But four centuries earlier Abu Taqiyya's organizational options were incomparably more limited.

The Middle East's golden age of entrepreneurship was over long before Abu Taqiyya came on stage. This is not to endorse the view, popular in some circles, that the region experienced an economic decline in some absolute sense. Although Abu Taqiyya did not travel to China, he and his fellow businessmen operated within an economy at least as large as that of a few centuries earlier, through organizations every bit as advanced. What differed is the wider global economy. Europe's commercial institutions had undergone cumulatively revolutionary transformations that were about to turn much of the remaining world, including the Middle East, into an underdeveloped zone.

There was a decline in economic performance, then, only in a relative sense. Abu Taqiyya's exploits, phenomenal when viewed through the lens of a specialist in Middle Eastern studies, look less impressive to a business historian familiar with the scale, longevity, and structural complexity of coeval businesses in England and Holland. By Abu Taqiyya's time, Middle Eastern entrepreneurs were already institutionally disadvantaged vis-à-vis their western contemporaries. Their handicap was to worsen for another quarter-millennium, until the initiation of fundamental reforms.

During the period when the organizational handicap of the Middle East worsened, the challenges faced by its entrepreneurs in the private economy were smaller than those of their western counterparts. In effect, it was caught in an equilibrium trap whereby the paucity of major entrepreneurship perpetuated itself by limiting the disequilibria presenting opportunities for basic innovations in production and commerce. Had merchants of Abu Taqiyya's generation attempted, say, to establish direct commercial relations with the Americas, the financial, navigational, and communicational challenges alone would have created major opportunities for innovation; and the consequent 
entrepreneurship might have created further dislocations, thus stimulating additional creative responses.

\section{Effects of Islam on Attitudes toward Innovation}

We have seen that certain distinctly Islamic institutions played critical roles in the broader institutional stagnation of the Middle East. The Islamic inheritance system limited incentives to modernize Islamic contract law, which assumed its classical form around the tenth century. Traditional Islamic contract law was well suited to the personal exchange prevalent in the medieval global economy. However, it became increasingly dysfunctional as global commerce, and then gradually commerce within the Middle East, became progressively more impersonal. Over the ages, then, Islam influenced the supply of entrepreneurship and productivity of entrepreneurs through its effects on the capacity to pool capital, expand commercially, engage in longlasting ventures, and preserve successful businesses.

In the medieval era, such effects would have been considered favorable. This is clear from the diffusion of Islamic law to areas far removed from Islam's heartland. During the half-millennium preceding the Industrial Revolution, they turned into handicaps, which became crippling when technological progress boosted the economic advantages of economic institutions designed to support complex economic exchange. Reformers who subsequently transplanted modern economic institutions to the Middle East were motivated by the very same impulses that drove the earlier diffusion of Islamic law: preserving and improving economic competitiveness.

The proposed relationship between Islam and entrepreneurship conflicts with arguments that invoke fatalism or conformism as fundamental Islamic attributes. Where scholars such as Patai and Sayigh propose a permanent handicap integral to Islam's ethos from the start, the present mechanism highlights the effects of changing circumstances. Islamic contract law became a handicap for entrepreneurs only as people outside the region developed the institutions of impersonal exchange. But one can reject the empirically untenable "religious fixity" claim embedded within the Patai and Sayigh theses without eliminating the possibility of attitudinal effects rooted in religion, or 
mediated by it. In principle, attitudes harmful to innovation, creativity, or risk taking could have emerged at any time, early in Islamic history or much later.

In Abu Taqiyya's time, coffee producers, traders, and consumers encountered opposition based, formally, on the notion that "black water" amounted to bid ' $a$ - a harmful innovation incompatible with Islam. This term entered Islamic discourse in the early days of the religion, to characterize practices not approved in the brief period up to the Prophet's death in 632. It is thus the converse of sunna-standards introduced by Muhammad and his pious companions. In its strictest form, bid ' $a$ served to dismiss as unIslamic every commodity, habit, and idea unknown in Arabia during Muhammad's

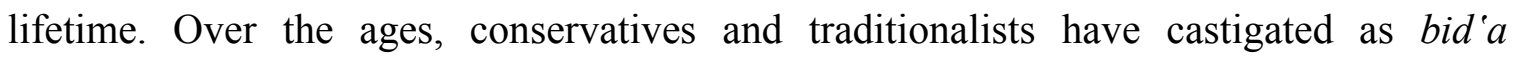
innovations ranging from the table and football to the printing press, the telegraph, and the radio. ${ }^{33}$ The charge that coffee drinkers reap hell-fire was neither the first nor the last time that opponents of innovation have sought legitimacy from Islamic tradition.

Yet, the Islamic opposition did not keep Abu Taqiyya from developing the Egyptian market for coffee. Over the long run, in fact, the anti-coffee campaign failed momentously. In sixteenth-century Arabia many clerics urged their congregations to destroy coffeehouses. A half-millennium later, leaders of Saudi Arabia's puritanical Wahhabi sect proudly serve coffee to their guests, treating it as an ancient Arab delicacy, usually without an awareness of the history of Arab and Islamic resistance to this custom. Numerous other innovations have gained Islamic legitimacy following a period of fervent resistance. In the early 1960s Wahhabi leaders opposed television. It violates the Islamic ban on graven images, they said, and might encourage idolatry. They led riots that the Saudi police was able to quell only by firing on demonstrators. Once Wahhabi leaders understood television's immense potential as an instrument of religious indoctrination, they promptly discovered that it falls, after all, within the sunna. "Someday a man will be able to see his brother standing on the other side of the mountain," they found that Muhammad had said, thus blessing television almost fourteen centuries in advance. ${ }^{34}$

\footnotetext{
${ }^{33}$ Talbi (1960), "Les Bida',"; Lewis (1993), Islam in History, pp. 283-84.

${ }^{34}$ Lackner (1978), A House Built on Sand, pp. 84-88; and Boyd (1973), "An Historical and Descriptive Analysis of the Evolution and Development of Saudi Arabian Television, 1963-1972," especially pp. $107-$ 09. For broader analyses of religious opposition to technological change in Saudi Arabia, see Al-Rasheed (2002), A History of Saudi Arabia, chaps. 2-4; and Steinberg (2005), "The Wahhabi Ulama and the Saudi State."
} 
The use of traditionalist rhetoric to discredit innovation is not unique to Islam. Every society, past and present, harbors groups who defend the local culture, or a local industry, or a way of life by characterizing innovators as unpatriotic, irreligious, or enemies of the local culture. Witness the French campaigns against McDonalds, fought not for reasons of health but on the ground that it threatens the "French way of life."35 Just as Sunni religious scholars in Abu Taqiyya's Cairo portrayed coffee as un-Islamic to weaken their Sufi rivals, so Parisian restaurant owners wrap themselves in the French flag to intimidate the new fast food industry and its patrons. In and of itself, then, episodes involving accusations of bid'a do not make Islam particularly inhospitable to entrepreneurship.

In any case, just as opponents of innovation may invoke religion, so too can its promoters. The term bid' $a$ rarely appears in the Quran, and none of its usages carries the pejorative connotation that it was to acquire. On that basis, supporters of particular innovations, and of receptivity to innovation in general, have sought to turn the tables on religious conservatives by arguing that the concept of bid' $a$ is itself bid ${ }^{\prime} a{ }^{36}$ Others tried to restrict the meaning of the concept to exclude useful innovations that are not demonstrably un-Islamic. Al-Shafi'i (767-821), the leading contributor to one of Islam's four major schools of law, held that bid $^{\prime} a$ encompasses only innovations that contradict the Quran, the sunna, and the consensus (ijmā') of the Muslim community. It does not subsume innovations that no one contests. By this logic, all bid' $a$ is blameworthy, but not all innovation is bid ${ }^{\prime} a{ }^{37}$ Still other theologians amend the meaning of bid ' $a$ to allow for a distinction between "bad bid 'a" and "good bid'a." In their view, only the former qualify as sinful errors that lead to hell. Novelties beneficial to the Muslim community constitute good bid ${ }^{3}$. $^{38}$

Throughout Islamic history, then, there have religious functionaries to whom entrepreneurs could turn to obtain religious support for their innovations. As coffee was spreading through Cairo, one center of opposition was al-Azhar, the city's main college

\footnotetext{
${ }^{35}$ For critical perspectives on modern campaigns against cross-cultural fertilization, see Lowenthal (1996), Possessed by the Past; and Cowen (2002), Creative Destruction.

${ }^{36}$ Talbi (1960), "Les Bida'," pp. 73-76.

${ }^{37}$ Talbi (1960), "Les Bida'," pp. 62-63.

${ }^{38}$ We know of such revisionist views partly through treatises that sought to discredit them. See Fierro, (1992), "The Treatises against Innovations (Kutub al-bida )"; and Labib (1970), "The Problem of the Bida" in the Light of an Arabic manuscript of the $14^{\text {th }}$ Century."
} 
and congregational mosque. A renowned al-Azhar preacher declared coffee forbidden. But other al-Azhar clerics sided with the proponents of legalization. Adopting an experimental approach, a judge of the Hanafi school of law held a council where he offered coffee to all participants, and then waited for signs of intoxication such as slurred speech, drowsiness, and melancholy. Finding none, he ruled, to the delight of the bourgeoning coffee sector, that coffee is permissible under Islamic law. ${ }^{39}$

The printing press offers another example of an innovation whose proponents were able to counter religious opposition through religion itself. For more than two centuries after the invention of the printing press in Europe (1450), Middle Eastern guilds of scribes opposed the establishment of local printing presses (except by minorities, to print books in their own languages). Authoritative knowledge could only be transmitted, they said, from person to person, for example, a calligrapher to the buyer of the handcopied book. Printing, by giving the producer anonymity in the eyes of buyers, would weaken the authority of the learned class and, hence, Islam itself. The demand for books being very low, for numerous generations no significant counter-pressures arose. By the early eigteenth century, however, such a lobby did emerge. It argued that the printed book would preserve, if not strengthen, existing patterns of religious authority. ${ }^{40}$ Asked to rule on the legality of the printing press, an influential Istanbul cleric said the following:

God knows what's best! If someone cognizant of printing technology and capable of manufacturing fonts can reliably reproduce hand-written texts, and if his enterprise offers the advantages of speedy production, easy copying, and prices low enough to put books within everyone's reach, and, finally, if proficient proofreaders are available, the enterprise is praiseworthy and deserving of support. ${ }^{41}$

Charges of bid'a undoubtedly had a retarding effect on the diffusion of some innovations. They would also have dampened the incentives for entrepreneurship. However, in and of themselves they cannot explain why, after several centuries of

\footnotetext{
${ }^{39}$ Hattox (1985), Coffee and Coffeehouses, pp. 39-40.

${ }^{40}$ Robinson (1993), "Technology and Religious Change," especially pp. 239-42; Berkes (1998), The Development of Secularism in Turkey, pp. 36-50; Babinger, Müteferrika ve Osmanlı Matbaası, pp. 9-11.

${ }^{41}$ Quoted by Babinger (2004), Müteferrika, p. 13 (my translation).
} 
innovative Muslim rule, the Middle East lost some of its institutional dynamism. After all, the concept of bid' $a$ was already present in the golden age of Middle Eastern entrepreneurship. It was available to opponents of innovation in the eighth century when Muslim entrepreneurs replaced fragile and expensive papyrus with Chinese paper, and then founded paper mills to produce Baghdadi paper, a fine substitute. ${ }^{42}$ Likewise, it was present during the ninth century as Muslim jurists were continuing to develop what was to become classical Islamic contract law. The organizational forms used by Abu Taqiyya and other towering entrepreneurs could have been castigated as un- Islamic, on the ground that they were not identical to those used by Muhammad and his companions. If bid' $a$ charges were indeed made to prevent organizational development in the early Islamic centuries, the evidence has not survived. What we do know is that the partnership forms used by Abu Taqiyya gained full legitimacy in the eyes of Muslim authorities.

\section{Stabilizing Effects of Islam's Self-Image of Timeless Perfection}

If one channel through which Islam influenced the supply of entrepreneurship was the doctrine of bid $^{\prime}$ a, a possibly more significant channel involved the teaching that Islam instituted, for all time, a necessarily perfect social order. Islam promotes the view that the Quran, which was revealed to the last of a long line of Prophets, embodies the unaltered words of God. By implication, it outlines a way of life that cannot possibly be improved upon. This presumption of perfection may serve, and in certain contexts has served, as a rationale for immobility: in an already flawless social order, innovations cannot yield benefits and may well do harm.

As a matter of practice, of course, no one has ever acted as though the social order is, literally, beyond improvement. In the face of changing circumstances, novel opportunities, and new problems demanding fresh thinking, successive generations of Muslims have routinely responded with creative solutions. Moreover, such solutions have commonly secured acceptance from Islam's schools of law. They have also gained an association, in the popular imagination, with traditional Islam. Islamic contract law offers a case in point. It took more than a quarter of a millennium for the key features of Islam's contracting principles to assume their classical forms. Along the way, myriads of

\footnotetext{
${ }^{42}$ Ashtor (1956), "The Kārīmi Merchants,” pp. 99-100.
} 
refinements occurred, many of them in response to practical problems that could not even have been imagined during Muhammad's lifetime, let alone solved. ${ }^{43}$ In actuality, therefore, Islamic contract law was constantly in flux. Understandings of what is properly Islamic gradually evolved. In this context, as in others, the evolution of Islamic doctrine involved reinterpretations of the Quran, along with additions to compendia of Muhammad's remembered words and deeds.

The challenges often differed across localities, which led to variations in the adopted solutions. Some of these variations translated into differences among the major schools of law: Hanafi, Maliki, Shafi'i, and Hanbali. On the specifics of contract law, for instance, these schools did not always rule identically. ${ }^{44}$ In certain domains, attachment to doctrine was always tenuous to begin with, so variations across time and space were particularly pronounced. Temporal and geographic variations in the resource base inevitably led to wide variations in tax practices. What a wheat grower paid in taxes differed greatly between, say, Turkey and Egypt, and, in any one country, between the sixteenth and eighteenth centuries. ${ }^{45}$

However, neither the transformations of practices associated with Islam nor their geographic diversification received formal approval. On the contrary, a steady rhetoric of institutional fixity effectively denied legitimacy to the process of innovation. Moreover, the fabrication of ostensible Islamic precedents for diverse innovations helped to erase from the collective memory the innovativeness of past Muslims and the dynamism of Islamic history. The consequent metamorphoses of the collective memory then kept new generations from appreciating how much more comfortably they themselves lived than earlier generations of Muslims, including the first Muslim community in seventh-century Arabia.

The process of absorbing changes and borrowings into Islam without conceding the plasticity of Islamic civilization also denied status to innovators. The founders of the Middle East's paper industry were not remembered or celebrated as entrepreneurs who spotted a useful Chinese commodity, marketed it locally, and then developed a

\footnotetext{
${ }^{43}$ Udovitch (1970), Partnership and Profit in Medieval Islam, especially chaps. 1, 7.

${ }^{44}$ Udovitch (1970), Partnership and Profit in Medieval Islam, chaps. 2, 4-5; Nyazee (1999), Islamic Law of Business Organization, chaps. 7, 10-16.

${ }^{45}$ İnalc1k (1994), “The Ottoman State,” pp. 55-154.
} 
technology for manufacturing a local variant. Nor, for that matter, were the generations of jurists who developed Islamic contract law remembered as institutional architects. They were treated as interpreters rather than innovators, as discoverers of an all-encompassing, fixed, and eternally perfect legal system rather than as creative legislators in their own right. Islam's rhetoric of institutional fixity would have discouraged entrepreneurship both by underrating its social significance and by denying social rewards to individual innovators.

From antiquity to the present, scores of towering social thinkers have observed how the esteem of others influences human actions. ${ }^{46}$ Insofar as Islam's self-image of timeless perfection required the denial of esteem to Muslim innovators, it would have limited incentives to develop new commodities, invent new production processes, and concoct legal reforms, among other possible entrepreneurial activities.

\section{Clerical Impediments to Innovation}

Before the modern era, Middle Eastern entrepreneurs operated within a legal system based, in principle, on divine revelation. In practice, jurisconsults (muftis), some of whom lacked ties to political authorities, extended and modified the law through advisory opinions (fatwas) regarding dilemmas brought before them. Likewise, stateappointed judges (kadis) routinely found creative solutions to daily conflicts. ${ }^{47}$

Traditionally neither innovative religious opinions nor the creative judgments of Islamic courts were treated as legal advances of broader relevance. No system existed for publicizing the evolution of the law to produce general precedents. One result was a duplication of judicial effort: judges had to resolve common disputes by going back, at each occurrence, to first principles. Although news of judicial decisions could travel, the lack of a system of granting authority to precedents would have hamstrung legal development. It would also have reinforced the above-discussed perception of institutional fixity. The former effect would have limited entrepreneurial capabilities, and latter would have dampened the rewards.

\footnotetext{
${ }^{46}$ For a recent example, see Brennan and Pettit (2004), The Economy of Esteem.

${ }^{47}$ Masud, Messick, and Powers (1996), "Muftis, Fatwas, and Islamic Legal Interpretation."
} 
Where the prevailing interpretation of the law posed great inconveniences, a common response was to circumvent the law through casuistry (hiyal). For example, in places where the Islamic ban on riba, an ancient Arabian institution, was treated as a generalized prohibition of interest, interest-bearing loans were extended through a double sale, or by disguising interest charges within currency exchanges, or by overpricing an exchanged commodity, among other such stratagems. The use of casuistry to meet common needs would have elevated transaction costs. ${ }^{48}$

It is the effects on entrepreneurial opportunities that matter here. Although casuistry provided a cheap method for legitimizing simple financial arrangements, it was of little use with regard to complex contracts involving large groups pooling resources for long periods. The parties to such contracts would generally insist on transparency, which is precisely what casuistry is meant to overcome. Had Abu Taqiyya attempted to form, say, a corporation, potential shareholders would have wanted its charter to specify their rights. They would also have insisted on credible measures to monitor its financial flows and enforce its promises. Casuistry and surreptitious reinterpretation were poorly suited, then, to institutional modifications and innovations of the extent necessary to establish the infrastructure for impersonal exchange.

The point may be supported through the greatest privately initiated Middle Eastern institutional innovation of the half-millennium preceding the Industrial Revolution: the emergence of a "cash waqf" sector. A waqf is an unincorporated trust established under Islamic law for the provision of a designated social service in perpetuity. Traditionally, its corpus had to consist of real estate; no portion of an endowment could be liquid. Because every waqf was considered sacred, endowed assets gained considerable immunity against expropriation. For this reason, and also because founders and their families could claim part of its income, the waqf became a very popular wealth shelter. Around the sixteenth century, depending on the area, waqfs owned between a quarter and half of all arable land and urban real estate. ${ }^{49}$

As far back as the eighth century, which is when the waqf of immovables emerged, professional moneylenders, whose wealth was largely liquid, sought to bend the

\footnotetext{
${ }^{48}$ Kuran (2005a), "The Logic of Financial Westernization in the Middle East," pp. 597-602.

49 Kuran (2001), "The Provision of Public Goods under Islamic Law."
} 
adopted rules by forming waqfs with liquid endowments. Uncommon for many centuries, in the fifteenth century cash waqfs started spreading rapidly, mainly in Turkey and the Balkans. Their rising popularity provoked intense religious controversy, not unlike today's clashes over abortion. In the minds of conservative clerics cash waqfs violated both waqf law and the presumed ban on interest. Liberal clerics, some of them investors in cash waqfs themselves, defended the innovation on the basis of its revealed usefulness, as evidenced by its popularity. ${ }^{50}$

The vast majority of all cash waqfs were minuscule as measured by assets, and they lent primarily to consumers for short terms. ${ }^{51}$ As with a bank, a cash waqf could maintain capital in perpetuity. But unlike a bank, it could not lend on a large scale by pooling the savings of multiple individuals. In principle, it could have metamorphosed into a financial institution we would now recognize as a bank. Clerics could have looked the other way as it effectively acquired legal personhood. They might also have reinterpreted waqf law to facilitate waqf mergers. Specifically, just as the traditional restriction on waqf assets was effectively rescinded under pressure from moneylenders, so the waqf rule requiring assets to be used in strict conformity to its founder's stipulations might have been relaxed to allow asset pooling on the part of later generations of caretakers (mutawallis).

The key difference between the two challenges-legitimizing the cash waqf and allowing flexibility in the use of capital-lay in the externalities involved. The act of endowing liquid capital produced no obvious negative externality. Indeed, no one could claim credibly to be harmed directly from broadening the range of endowable assets. By contrast, waqf mergers would have drawn objections from the designated beneficiaries of individual waqfs. Some beneficiaries would have argued, within reason, that mergers placed their entitlements at risk. Transforming the waqf sector into a veritable banking sector would have required, then, collective action on a large scale to counter the inevitable resistance. This is probably one reason why the moneylenders who used the

\footnotetext{
${ }^{50}$ Mandaville (1979), “Usurious Piety,” pp. 297-300, 306-08.

${ }^{51}$ Çizakça (2000), A History of Philanthropic Foundations, p. 48.
} 
waqf of immovables as the basis for a new financial institution did not take the next logical step of forming banks. ${ }^{52}$

The cash waqf was well suited to personal exchange. Its caretaker made loans to members of trust-based networks, and ordinarily he lent only to people known to him personally. A bank belongs to a more complex economy in which impersonal exchange is becoming, or has become, the norm. So obstacles to transforming the cash waqf into a veritable bank would have hampered the scale of entrepreneurship by restricting the supply of credit. Insofar as clerical concerns were to blame, they thus harmed entrepreneurial performance, leaving Middle Easterners handicapped in the evolving modern economy.

Because the cash waqf did not metamorphose into a bank, establishing a financial system suitable to industrialization required fundamental legal reforms through either a massive reinterpretation of Islamic law or legal secularization at least on matters pertaining to commerce and finance. It is the latter option that Middle Eastern reformers ultimately took in the nineteenth century. ${ }^{53}$ The timing of the reforms speaks volumes. Territorial losses, political instability, and protracted economic crises had lowered popular resistance to broad reform.

\section{The State's Impact on Entrepreneurial Capabilities}

All states have help to solve collective action problems. So it has been in the Middle East. Both before and after the rise of Islam, Middle Eastern states protected property rights, administered justice, defended borders, and spearheaded campaigns of territorial expansion. In pursuing such goals they routinely learned from their mistakes, embraced new technologies, and made organizational adaptations. ${ }^{54}$ Although subjects benefited unequally, most did better than possible in a Hobbesian world of anarchy. In

\footnotetext{
${ }^{52}$ A possible objection to this interpretation is that new cash waqfs could have been granted flexibilities without threatening any existing beneficiaries directly. True, but a ubiquitous threat was that of concessions eroding public morality in general. Indeed, the fear of the "slippery slope" has been a common theme of resistance to Islamic reinterpretation. Mandaville, "Usurious Piety," pp. 304-06, documents that it was an element of the conservative rhetoric exhibited during the cash waqf controversy. For examples from other contexts, see Zilfi (1988), The Politics of Piety, chap. 4.

${ }^{53}$ Kuran (2005b), "The Logic of Financial Westernization in the Middle East," pp. 608-12.

${ }^{54}$ Ágoston (2005), Guns for the Sultan, develops all these points in his analysis of the Ottoman arms industry. For complementary observations, see İhsanoğlu (2004), chaps. 2-3.
} 
principle, states might also have assisted the advancement of commercial institutions. They could have taken steps to facilitate, say, large-scale entrepreneurship involving long-term investments. In England, home to some of the earliest business corporations, the Crown assisted their development through charters.

Had a similar scenario played out in the Middle East, it would have marked an exception to a general pattern: minimal state support to private economic activity. Traditionally, Muslim-governed states monopolized the provision of law and order. They also raised taxes, of course, where possible directly, more often indirectly through tax farmers who purchased collection rights through auctions. However, after Islam's initial period, Middle Eastern states pursued no major initiatives to develop the institutional infrastructure of commerce. Until the nineteenth century, when efforts to codify Islamic law were launched, the judges of Islamic courts interpreted contracting rules in a decentralized manner, without state direction.

Nor did states of the region play the leading role in the provision of social services. In the great cities of the medieval Middle East, social services were supplied largely by waqfs. It was through waqfs that schools, hospitals, soup kitchens, fountains, and even roads and parks were ordinarily financed and maintained. The caravanserais (fortified inns for caravans) found on the region's commercial arteries were usually organized as waqfs. True, rulers were not indifferent to the allocation of waqf resources. Aware that the vast assets of the waqf system could serve their strategic objectives, they induced waqf-founding elites, especially their relatives, to favor particular regions and sectors. Nevertheless, until modern times many services now provided centrally through such agencies as municipalities, highway administrations, education boards, and water departments were supplied in a remarkably decentralized manner. In this respect, the governance of pre-modern Middle Eastern societies conformed to the ideals of modern libertarianism. ${ }^{55}$

Just as Mamluk, Ottoman, and other Middle Eastern rulers sought to use the waqf system to their own advantage, so in various contexts they tried to benefit from the activities of merchants and producers. Political stability required major cities to remain well stocked with staple commodities, so protections were extended to businessmen

\footnotetext{
${ }^{55}$ Kuran (2001), "Provision of Public Goods under Islamic Law."
} 
belonging to relevant supply chains. Rulers also imposed economic restrictions, or provided economic privileges, to alleviate perceived threats to favored constituencies. For instance, certain guilds and traders were awarded court-enforced monopoly or monopsony powers. ${ }^{56}$ There are examples, finally, of rulers protecting long-distance traders with whom they formed partnerships. Ayyubid and Mamluk sultans extended financing as well as commercial privileges to the Karimi traders who in the twelfth and thirteenth centuries dominated the Indian Ocean spice trade. ${ }^{57}$ Shah Abbas I of Iran (r. 1587-1629) and several of his successors invested in the cross-continental silk trade of the Armenians based in New Julfa. They also gave this community of merchants military and diplomatic support. ${ }^{58}$

Strikingly absent are state initiatives to improve commercial capabilities in general. The building of centralized urban markets, or grand bazaars, is the major exception that proves the point. One motive for establishing grand bazaars was to stimulate commerce. However, rulers wanted also to facilitate the monitoring of trade flows for the purpose of taxation. In principle, the lure of a larger tax base could have led sultans to improve the organizational capabilities of merchants operating under Islamic law. They might have encouraged clerics to reinterpret the Islamic inheritance system in a manner helpful to the preservation of successful businesses, or to introduce into Islamic law a formal distinction between natural and legal persons. However, if any pre-modern statesmen detected the advantages of such reforms, they took no initiatives that left historical traces. During financial emergencies, rulers doubled their efforts to locate untapped sources of wealth. But they did not pursue institutional innovations to stimulate wealth creation. Until the nineteenth century, they did not consider the prevailing means for resource pooling, or the scale of entrepreneurship, a problem calling for state intervention.

On the contrary, at times they actively opposed institutional innovations aimed at enhancing commercial capabilities. In 1695, faced with a budget crisis in the midst of military retreats, the Ottoman government converted a large number of short-term tax

\footnotetext{
${ }^{56}$ For evidence see the following cases from Istanbul court register no. 9, which covers the period 1661-62: $56 \mathrm{~b} / 1,64 \mathrm{a} / 5,121 \mathrm{a} / 1,125 \mathrm{~b} / 2,171 \mathrm{~b} / 2,190 \mathrm{~b} / 3,262 \mathrm{~b} / 3$.

${ }^{57}$ Ashtor (1956), "The Kārīmi Merchants."

${ }^{58}$ Curtin (1984), Cross-Cultural Trade in World History, chap. 9; McCabe (1999), The Shah's Silk for Europe's Silver, especially chap. 4.
} 
farms into life-term tax farms (malikanes). The goal was to raise the down payment required to purchase a tax farm, effectively borrowing against future revenue. Of interest here is that the lengthening of the tax-farm terms induced a potentially far-reaching innovation in financial markets. In order to meet the higher payments required to win auctions, tax farmers took to forming partnerships meant to last for many years. Predictably, personal emergencies and business opportunities made certain members of these partnerships attempt to sell their rights. Under Islamic law, strictly interpreted, the transfers were illegal; at each withdrawal the pre-existing partnership became null and void, requiring the negotiation of a new contract. However, tax farmers and the state had a common stake in the transferability of shares. Accordingly, an officially tolerated but informal market in tax farm shares took hold. ${ }^{59}$

Had this development run its course, the region might have developed organized stock exchanges organically, rather than as part of a top-down reform package involving the transplant of foreign institutions. However, the Ottoman government began to fret, on the one hand, about keeping track of ownership patterns and, on the other, about the growing clout of tax farmers. In the early nineteenth century it restricted the divisibility of tax farm ownership, and then started confiscating tax farms. These moves alleviated pressures for further innovations in private financial markets. The first organized stock markets of the empire went into operation in 1866, in a period when the region saw the establishment of its earliest local banks, the adoption of modern accounting systems, and the founding of secular courts to operate alongside traditional Islamic courts. ${ }^{60}$

The Ottoman government's opposition to the transferability of enterprise shares, like so many other state policies in Middle Eastern history, are commonly attributed to the economic conservatism of ruling elites. ${ }^{61}$ Moreover, conservatism on the part of rulers is often treated as a basic determinant of recorded entrepreneurial deficiencies. Yet, the ideological tendencies of political elites were not formed or maintained in a vacuum. Non-state actors such as craftsmen, shopkeepers, traveling merchants, and moneylenders contributed to their development. Hence, a full explanation for the economic

\footnotetext{
${ }^{59}$ Çizakça (1996), A Comparative Evolution of Business Partnerships, pp. 159-86.

${ }^{60}$ For overviews of these developments, see Liebesny (1975), The Law of the Near and Middle East; Anderson (1968), "Law Reform in Egypt."

${ }^{61}$ Genç (2000), Devlet ve Ekonomi, pt. 1.
} 
conservatism of state officials, or of their indifference to the institutions governing entrepreneurial capabilities, must take account of factors shaping ideologies prevalent within the business community.

For reasons already identified, commercial sectors of the pre-modern Middle East were atomistic. Enterprises formed through contracts among non-kin were usually small and ephemeral. Exchanges tended to take place among people known to one another. Accordingly, the worldviews of merchants, investors, and producers were shaped by the exigencies of personal exchange. And in the absence of fundamental changes in commercial and financial practices, these groups did not get habituated to thinking about new institutional possibilities. Their own contentment with the institutional status quo would have limited the stimuli inducing statesmen to think about commercial capabilities. Had businessmen been more creative in regard to the structure of commerce, they would have initiated debates on institutional alternatives, forcing statesmen to ponder the desirability of reforms. In the process, at least some political elites would have discovered the long-term advantages of enhancing the scale of entrepreneurship.

The observation that Middle Eastern statesmen were economically conservative is often advanced alongside the view that in western Europe, fount of the modern economy, statesmen were relatively more enlightened on economic matters. English and French rulers of the seventeenth century certainly helped their merchants advance globally. Also true is that their Ottoman and Safavid counterparts, insofar as they tried to assist merchants, were relatively ineffective. However, recorded differences in official ideology do not explain, in and of themselves, the observed gaps in commercial performance. In both the West and the Middle East, the economic worldviews of statesmen co-evolved with those of the business community. Moreover, in each region the dynamics of commercial institutions affected ideological development.

Given the immense economic weight of the waqf sector in the pre-modern Middle Eastern economy, no inquiry into the region's entrepreneurial capacity would be complete without commentary on how the waqf shaped economic creativity. Among the literal meanings of waqf is "to stop" and "to make dependent." 62 These meanings convey one of the basic principles of the waqf: "static perpetuity." It entails the immobilization

${ }^{62}$ Wehr (1980), A Dictionary of Modern Written Arabic, pp. 1091-94. 
of endowed assets for the purpose specified in the waqf charter. If a waqf was established to build and then maintain a fountain, ordinarily its assets had to fund that purpose in perpetuity. There were conditions, of course, under which the assets could be reallocated. If the neighborhood around an endowed fountain got deserted, a judge might allow the reallocation of the underlying assets. Under less severe changes in economic conditions, however, the principle of static perpetuity commonly locked resources into inefficient uses. $^{63}$

When a successful merchant established a waqf in order to gain material security, resources thus got transferred from a sector in which they were mobile to one in which more or less enforced allocational restrictions, and therefore additional obstacles to entrepreneurship, came into play. If Middle Eastern merchants were held back by inadequate means for forming large enterprises, the caretakers of waqfs were generally barred altogether from pooling resources. Assets that flowed from the commercial sector to the waqf sector harmed entrepreneurial capacity in two other ways. Because courts had supervisory authority over waqfs, as a matter of practice caretakers trying to preserve the value of waqf assets had less freedom than managers of private portfolios. Waqf rules limited institutional change also by barring the use of resources for political purposes.

The waqf is not among Islam's original institutions. Its history extends only to the eighth century, a century after the advent of Islam. Although little is known about its emergence, it came to serve as an antidote to weak property rights, for the benefit of high state officials, many of them major landowners. In modifying and enriching Islamic law, state officials thus helped to solve a social problem that they themselves aggravated through predation. If for a millennium resources then flowed into a sector that limited allocational flexibility and institutional creativity, this is an unanticipated consequence of that particular institutional choice.

Are the waqf's effects on the supply of entrepreneurship rooted, then, in Islam or in state policies? These two effects cannot be disentangled. State policies influenced the specifics of Islamic waqf law. By the same token, the state itself governed in the name of Islam, which accepts no formal separation between religion and state. The antimercantilist tendencies of pre-modern Middle Eastern states, the immense popularity of

\footnotetext{
${ }^{63}$ Kuran (2001), "Provision of Public Goods under Islamic Law,” pp. 861-69.
} 
the waqf as a wealth shelter, and the region's growing entrepreneurial deficiencies in the face of global institutional transformations are all manifestations of a mutually enforcing set of social mechanisms.

\section{Recapitulation and Implications for the Economic History of the Middle East}

The foregoing arguments discredit both of the categorical views on the links between Islam and entrepreneurship in Middle Eastern history. Neither the categorically negative view nor the categorically positive view stands empirical scrutiny. The region's entrepreneurial performance in relation to the prevailing global standards has varied over time. Although the variations stem from Islamic institutions, the mechanisms at play have differed from those commonly invoked in the literature.

The historical record belies the claim that Islam per se has impeded entrepreneurship by inculcating conformism or fatalism. For the better part of the past 14 centuries, the Middle East has not appeared deficient in entrepreneurship. Moreover, even in recent centuries Middle Easterners in general, and Muslims in particular, have undertaken the sorts of activities we associate with entrepreneurs.

The diametrically opposed view, promoted most vocally by Islamists, that Islam offers institutions necessarily beneficial to entrepreneurship flies in the face of the historical transformations associated with economic modernization. Islamic institutions that served innovators well in the medieval global economy became dysfunctional as the world made the transition to impersonal exchange. In the process, the relative entrepreneurial performance of the Middle East slipped. The observed deficiencies would have been greater, in fact, had the region not responded by transplanting various institutions of western provenance to supplement, and usually to supplant, their counterparts grounded in traditional Islamic law.

Making sense of variations in the region's relative entrepreneurial performance requires a nuanced analysis focused on the dynamics of entrepreneurial capabilities and possibilities. State policies are among the determinants of entrepreneurial opportunity and productivity. In Islam's early centuries, Middle Eastern states assisted commercial development through various means. Subsequently, they did little to improve entrepreneurial performance. They left the provision of services relevant to 
entrepreneurial productivity largely to waqfs, which came to control vast economic resources. Thus, the caravanserais that enabled merchants to travel long distances were financed through waqfs, as were schools that provided literacy and numeracy. Because the waqf sector designed to immobilize resources for particular ends, and thus to limit flexibility and innovation, its absorption of assets concentrated resources in a sector particularly inimical to entrepreneurship. The state fueled waqf formation insofar as its penchant for expropriation and arbitrary taxation made the wealthy seek to shelter assets. Islam played a role as well, and what secured its assets is their presumed sacredness.

Islam influenced Middle Eastern entrepreneurship also through several other channels. One entails the influence of clerics. Every generation of Muslim clerics included individuals opposed to one innovation or another. Their agitations imposed barriers to entrepreneurship, which would have lowered its supply. However, this resistance was never decisive, for innovations with broad social benefits always drew clerical support as well. The effects of clerical resistance may be likened to those of modern environmentalism. Land developers now face opposition from environmentalists who require them to prove, through costly legal procedures, that the environment will not suffer. The anti-growth campaigns of environmental lobbies have reduced investment in land development schemes, but hardly to the point of extinction. The lure of hefty gain makes investors overcome the opposition through counter-campaigns. Similarly, where Middle Eastern businessmen have considered innovation sufficiently profitable, opposition in the name of Islam has usually had no more than a retarding influence.

Opportunities for beneficial innovation are never self-evident. People with the requisite talents and motivations must first notice a problem, sense the possibility of creating a new demand, or discover that an existing demand may be met more efficiently. Whether entrepreneurs spot emerging opportunities depends partly on how well public discourse prepares them to do so. This brings us to a second channel through which Islam has affected entrepreneurship. Islam's self-image of timeless perfection required the Muslim learned community to downplay, even actively conceal, the dynamism responsible for its successes. It had to trace new developments to early Islam, promoting the fiction that Muslim generations after the first interpreted the Quran and drew lessons from the wisdom of the Prophet without innovating in any fundamental sense. Prior to 
mass communications, this myth, taught in schools and propagated through mosques, would have trained people to seek personal advancement through replicative activities. Accordingly, it would have dragged the Islamic world from the state of relatively high entrepreneurship characteristic of its first few centuries to one of relatively low entrepreneurship, under which the sense of fixity became more or less self-fulfilling.

The myth of timeless perfection helped, then, to destroy a social equilibrium whereby people experienced structural changes and witnessed advances in the private sector, replacing it with one that sustained a perception of continuity. This transformation depended critically on another linkage between Islam and entrepreneurship. Certain elements of Islamic law dampened individual incentives to build larger and longer-lasting commercial organizations, thus limiting entrepreneurial possibilities. In particular, Islam's egalitarian inheritance rules encouraged merchants and investors to keep their operations small and ephemeral, thus dampening incentives to refine traditional partnerships and develop tools of impersonal exchange. Any entrepreneur who noticed the limitations of Islamic partnerships and went looking for a more complex organizational form would have been stymied by the lack of an Islamic concept of corporation. These institutional limitations jointly dampened the pace of structural change in commerce and finance, thus facilitating the entrenchment of the myth of timeless perfection. The scale of commercial operations remained small in the Middle East even as Europeans developed the means for producing and exchanging on a massive scale. The waqf system, which controlled vast assets, offered no substitute for modern economic institutions, for it was designed to serve rigid goals.

The question of why the Middle East has experienced entrepreneurial deficiencies is part of a broader question of why it fell behind the West. In his voluminous writings, Max Weber invoked several factors as explanations: the inflexibility of Islamic law, failure to achieve legal formalization, sultanism (arbitrary personal rule), and lack of an ascetic streak fueling "salvation anxiety." ${ }^{, 64}$ The empirical relevance of the last factor has been discredited. ${ }^{65}$ But the first three have been invoked here as well, though using different terminology. Viewing them as fixed attributes of Islamic civilization, Weber

\footnotetext{
${ }^{64}$ Weber (1978), Economy and Society, pp. 572-76, 818-22, 1231-34.

${ }^{65}$ Turner (1978), Weber and Islam, chap. 1.
} 
suggested that they suppressed entrepreneurial drives. Here I have proposed that Weber asked the wrong question about the origins of Middle Eastern underdevelopment. The fundamental question is not which factors harmed economic advancement but why economically disadvantageous traits proved so persistent. Until the modern era, these traits were mutually reinforcing, and they drew strength also from laws limiting the scale and longevity of entrepreneurial projects.

\section{Lessons for Innovative Entrepreneurship in the Modern Middle East}

Motivations, beliefs, laws, regulations, and practices are all malleable. As such, any element of Islam that somehow came to harm the Middle East's relative entrepreneurial performance was always subject to reconsideration and modification. The massive reforms of the nineteenth century testify to the possibility of institutional change within domains long regulated in the name of Islam.

Those reforms enabled individual entrepreneurs to borrow from banks, form organizations with indefinite lives, trade enterprise shares, and track complex financial flows through modern accounting systems. They thus removed the obstacles that kept Middle Eastern enterprises atomistic and ephemeral. As of February 2007, Fortune's Global 2000, a list of the world's 2000 leading publicly traded companies as measured by sales, market value, assets, and profits, included 14 companies from Malaysia, 11 from Turkey, 5 from Saudi Arabia, 3 from Egypt, 2 from Pakistan, and 1 from Jordan, for a total of 36 companies headquartered in a predominantly Muslim country. ${ }^{66}$ The geographic diversity of this distribution shows that it is now possible to form giant private companies all across the Islamic world. Were Abu Taqiyya to come back to life, he would be bewildered by the new opportunities for pooling resources and preserving enterprises. He would recognize that modern organizational forms provide entrepreneurial capabilities unimaginable in seventeenth-century Egypt.

Throughout the Middle East, even in its poorest corners, institutional reforms of the past two centuries have removed obstacles to forming modern enterprises. Many of these reforms replaced ancient Islamic institutions with ones that emerged or reached maturity in western countries. This brings us back to Al-Afghani's claim that Muslims

\footnotetext{
${ }^{66} \mathrm{http}: / / \mathrm{www}$. forbes.com/lists. The list is updated regularly.
} 
lost economic standing when they ceased to practice authentic Islam. In fact, Muslims did not suffer economically as a result of transplanted institutions developed outside the purview of Islamic law. On the contrary, they expanded their entrepreneurial capabilities by leaps and bounds, and thus their economies. None of today's Global 2000 companies could operate under Islamic law. Institutions of foreign origins have contributed visibly to exponential growth in the region's absolute living standards.

There are grains of truth, however, in Al-Afghani's other claim, that European Christians gained economic strength because they were not really Christian. Although a majority of the Venetians, Dutch, and English who pioneered new commercial techniques or production methods practiced some form of Christianity, seldom did they look to the Bible or to ecclesiastical laws for solutions to business problems. The separation of Church and state early in the second millennium enabled European entrepreneurs to develop institutions within an essentially secular space, and generally without worrying about clerical reactions.

The history of Christianity is not, of course, a story of uniform or unilinear secularization. Eastern Christians responded to the meteoric rise of Islam not by trying to understand the social and economic factors behind this new religion's success but generally by treating it as punishment for their own wickedness, or that of their brethren. They inferred that God was instructing them to become better Christians. ${ }^{67}$ Following an analogous script, today's Islamists claim that to overcome the economic backwardness of the Islamic world, Muslims must first and foremost return to being good Muslims. In regard to economic life, they say, Muslims to reinstitute early Islamic practices. This preoccupation with purity and authenticity is blinding Islamists, along with assorted multiculturalists, to the incompatibility between Islam's traditional economic institutions and the modern global economy. It is also diverting the efforts of energetic and potentially creative Muslims from open-ended efforts to enhance economic productivity and efficiency to sterile debates about what is properly Islamic. Innovators are fretting about whether they will be accused of introducing forbidden practices, still known in certain circles as bid'a.

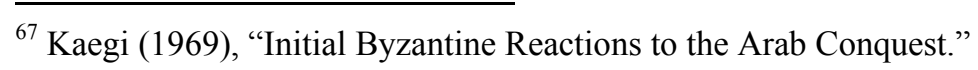


Not everyone in the Islamic world shares the Islamist agenda. Resistance from secularists of various shades fuels political instability. As the experiences of Sudan, Algeria, and Iraq demonstrate, people with skills and initiative move out of politically volatile areas, carrying with them their entrepreneurial talents. Although relatively pragmatic forms of Islamism are associated with upward mobility, its militant forms are manifestly harmful to entrepreneurial performance. ${ }^{68}$

To observe that today's entrepreneurs have access to modern organizational forms is not to say that the organizational history of the Middle East no longer matters. The persistently small scale of pre-modern profit-oriented enterprises and limitations on the use of waqf assets both blocked the development of civil society. In most parts of the Islamic world, authoritarian regimes have filled the resulting political vacuum. Facing scant resistance from private organizations, these regimes have been able to pursue interventionist economic policies that discourage private initiative and weaken rule of law.

The foregoing observations suggest that entrepreneurship in the Middle East can be stimulated through a multi-pronged strategy. Steps that strengthen the rule of law would help, as would policies that strengthen the private sector and civil society in general. Educating the public about the causes of the Islamic world's slip in economic standing would serve to build a consensus in favor of such reforms. Obstacles to entrepreneurship can be lowered also by publicizing the direct and indirect effects of Islamist efforts to reinstitute medieval economic practices.

What is not required is to familiarize the region with organizational forms conducive to entrepreneurship on a large scale. Nowhere do the organizational options of entrepreneurs remain limited to Islamic partnerships.

\footnotetext{
${ }^{68}$ Kuran (2004), Islam and Mammon, chap. 2. On the role of economically helpful effects of Islamism, see also Singerman (1995), Avenues of Participation, chaps. 3-4; and Özcan and Çokgezen (2006), "Trusted Markets."
} 


\section{References}

Abdullah, Thabit A. J. (2001). Merchants, Mamluks, and Murder: The Political Economy of Trade in Eighteenth-Century Basra. Albany: State University of New York Press.

Abu-Lughod, Janet L. (1989). Before European Hegemony: The World System A.D. 1250-1350. New York: Oxford University Press.

Aghassian, Michel and Kéram Kévonian (1999). “The Armenian Merchant Network: Overall Autonomy and Integration," translated by Cyprian P. Blamires. In Merchants, Companies and Trade: Europe and Asia in the Early Modern Era, edited by Sushil Chaudhury and Michel Morineau, pp. 74-94. Cambridge: Cambridge University Press.

Ágoston, Gábor (2005). Guns for the Sultan: Military Power and the Weapons Industry in the Ottoman Empire. Cambridge: Cambridge University Press.

Ahmed, Habib (2006). "Islamic Law, Adaptability and Financial Development." Islamic Economic Studies, 13: 79-101.

Al-Rasheed, Madawi (2002). A History of Saudi Arabia. Cambridge: Cambridge University Press.

Anderson, J. N. D. (1968). "Law Reform in Egypt: 1850-1950.” Pp. 209-30 in Political and Social Change in Modern Egypt, ed. P. M. Holt. London: Oxford University Press.

Ashtor, Eliyahu (1956). “The Kārīmi Merchants.” Journal of the Royal Asiatic Society, pts. 1-2: 45-56.

Ashtor, Eliyahu (1976). A Social and Economic History of the Near East in the Middle Ages. London: Collins.

Babinger, Franz (2004). Müteferrika ve Osmanlı Matbaası: 18. Yüzyılda İstanbul'da Kitabiyat, translated by Nedret Kuran-Burçoğlu, original German ed. 1919. Istanbul: Tarih Vakfi.

Berkes, Niyazi (1998). The Development of Secularism in Turkey. New York: Routledge, 1998; reprint of 1964 edition. 
Boyd, Douglas A. (1973). "An Historical and Descriptive Analysis of the Evolution and Development of Saudi Arabian Television, 1963-1972." Unpublished Ph.D. dissertation, Department of Mass Communication, University of Minnesota.

Brennan, Geoffrey and Philip Pettit (2004). The Economy of Esteem: An Essay on Civil and Political Society. New York: Oxford University Press.

Casale, Giancarlo (2006). "The Ottoman Administration of the Spice Trade in the Sixteenth-Century Red Sea and Persian Gulf." Journal of the Economic and Social History of the Orient, 49 (2): 1-29.

Casson, Mark C. (2003). The Entrepreneur: An Economic Theory, $2^{\text {nd }}$ ed. Cheltenham, U.K.: Edward Elgar.

Chaudhuri, K. N. (1985). Trade and Civilisation in the Indian Ocean: An Economic History from the Rise of Islam to 1750. Cambridge: Cambridge University Press.

Cohen, Hayyim J. (1970) "The Economic Background and the Secular Occupations of Muslim Jurisprudents and Traditionists in the Classical Period of Islam (Until the Middle of the Eleventh Century)." Journal of the Economic and Social History of the Orient, 13: 16-61.

Coşgel, Metin M. (2005). "Efficiency and Continuity in Public Finance: The Ottoman System of Taxation." International Journal of Middle East Studies, 37: 567-86.

Cowen, Tyler (2002). Creative Destruction: How Globalization is Changing the World's Cultures. Princeton: Princeton University Press.

Curtin, Philip D. (1984). Cross-Cultural Trade in World History. Cambridge: Cambridge University Press.

Çizakça, Murat (1996). A Comparative Evolution of Business Partnerships: The Islamic World and Europe, with Special Reference to the Ottoman Archives. Leiden: E.J. Brill.

Çizakça, Murat (2000). A History of Philanthropic Foundations: The Islamic World from the Seventh Century to the Present. Istanbul: Boğaziçi University Press.

Darling, Linda (1996). Revenue-Raising and Legitimacy: Tax Collection and Finance Administration in the Ottoman Empire. Leiden: E.J. Brill.

De Roover, Raymond (1963). The Rise and Decline of the Medici Bank, 1397-1494. Cambridge, Mass.: Harvard University Press. 
El-Gamal, Mahmoud A. (2006). Islamic Finance: Law, Economics, and Practice. Cambridge: Cambridge University Press.

Faroqhi, Suraiya (1999). Approaching Ottoman History: An Introduction to the Sources. Cambridge: Cambridge University Press.

Fierro, Maribel (1992). “The Treatises against Innovations (Kutub al-bida ).” Der Islam 69: 204-46.

Genç, Mehmet (2000). Osmanlı Imparatorluğunda Devlet ve Ekonomi. Istanbul: Ötüken.

Goitein, S. D. (1967). A Mediterranean Society, 1: Economic Foundations. Berkeley: University of California Press.

Hanna, Nelly (1998). Making Big Money in 1600: The Life and Times of Isma 'il Abu Taqiyya, Egyptian Merchant. Syracuse: Syracuse University Press.

Hattox, Ralph S. (1985). Coffee and Coffeehouses: The Origins of a Social Beverage in the Medieval Middle East. Seattle: University of Washington Press.

Hayek, Friedrich A. (1937). "Economics and Knowledge.” Economica, n.s. 4: 33-54.

Hourani, Albert (1983). Arabic Thought in the Liberal Age, 1798-1839, revised ed. Cambridge: Cambridge University Press.

Hourani, George F. (1995). Arab Seafaring, expanded ed. Princeton: Princeton University Press.

İhsanoğlu, Ekmeleddin (2004). Science, Technology and Learning in the Ottoman Empire: Western Influence, Local Institutions, and the Transfer of Technology. Aldershot, Hampshire, U.K.: Ashgate.

İnalc1k, Halil (1994). “The Ottoman State: Economy and Society, 1300-1600.” Pp. 9-409 in An Economic and Social History of the Ottoman Empire, 1300-1914, ed. Halil İnalc1k with Donald Quataert. New York: Cambridge University Press.

Kaegi, Walter E. J. (1969). "Initial Byzantine Reactions to the Arab Conquest." Church History, 38: 139-49.

Kirzner, Israel M. (1979). Perception, Opportunity, and Profit: Studies in the Theory of Entrepreneurship. Chicago: University of Chicago Press.

Kuran, Timur (2001). "The Provision of Public Goods under Islamic Law: Origins, Impact, and Limitations of the Waqf System." Law and Society Review, 35: 84197. 
Kuran, Timur (2003). "The Islamic Commercial Crisis: Institutional Roots of Economic Underdevelopment in the Middle East." Journal of Economic History, 63: 414-46.

Kuran, Timur (2004). Islam and Mammon: The Economic Predicaments of Islamism. Princeton: Princeton University Press.

Kuran, Timur (2005a). "The Absence of the Corporation in Islamic Law: Origins and Persistence.” American Journal of Comparative Law, 53: 785-834.

Kuran, Timur (2005b). "The Logic of Financial Westernization in the Middle East." Journal of Economic Behavior and Organization, 56: 593-615.

Labib, Subhi (1970). "the Problem of the Bida" in the Light of an Arabic manuscript of the $14^{\text {th }}$ Century." In Proceedings of the Twenty-Sixth International Congress of Orientalists, New Delhi, 4-10 ${ }^{\text {th }}$ January, 1964, vol . 4. New Delhi: International Congress of Orientalists.

Lackner, Helen (1978). A House Built on Sand: A Political Economy of Saudi Arabia London: Ithaca Press.

Leibenstein, Harvey (1968). "Entrepreneurship and Development." American Economic Review, 58: 72-83.

Lewis, Bernard (1993). Islam in History: Ideas, People, and Events in the Middle East, $2^{\text {nd }}$ ed. Chicago: Open Court.

Lewis, Bernard (2002). What Went Wrong? Western Impact and Middle Eastern Response. New York: Oxford University Press.

Liebesny, Herbert J. (1975). The Law of the Near and Middle East: Readings, Cases, and Materials. Albany: State University Press of New York Press.

Løkkegaard, Frede (1950). Islamic Taxation in the Classic Period, with Special Reference to Circumstances in Iraq. Copenhagen: Branner and Korch.

Lowenthal, David (1996). Possessed by the Past: The Heritage Crusade and the Spoils of History. New York: Free Press.

Mandaville, Jon E. (1979). "Usurious Piety: The Cash Waqf Controversy in the Ottoman Empire." International Journal of Middle East Studies, 10: 298-308.

Mannan, Muhammad A. (1970). Islamic Economics: Theory and Practice. Lahore: Sh. Muhammad Ashraf. 
Marcus, Abraham (1989). The Middle East on the Eve of Modernity: Aleppo in the Eighteenth Century. New York: Columbia University Press.

Masud, Muhammad Khalid, Brinkley Messick, and David S. Powers (1996). "Muftis, Fatwas, and Islamic Legal Interpretation.” In Islamic Legal Interpretation: Muftis and Their Fatwas, edited by Muhammad Khalid Masud, Brinkley Messick, and David S. Powers, pp. 3-32. Cambridge, Mass.: Harvard University Press.

McCabe, Ina Baghdiantz (1999). The Shah's Silk for Europe's Silver: The Eurasian Trade of the Julfa Armenians in Safavid Iran and India (1530-1750). Atlanta: Scholars Press.

Nyazee, Imran Ahsan Khan (1999). Islamic Law of Business Organization: Partnerships. Islamabad: Islamic Research Institute.

Özcan, Gül Berna and Murat Çokgezen (2006). "Trusted Markets: The Exchanges of Islamic Companies.” Comparative Economic Studies, 48: 132-55.

Palmer, Monte, Abdelrahman Al-Hegelan, Mohammed Bushara Abdelrahman, Ali Leila, and El Sayeed Yassin (1989). "Bureaucratic Innovation and Economic Development in the Middle East: A Study of Egypt, Saudi Arabia, and the Sudan." In Bureaucracy and Development in the Arab World, edited by Joseph G. Jabbra, pp. 12-27. Leiden: E.J. Brill.

Patai, Raphael (1983). The Arab Mind, revised edition. New York: Charles Scribner's.

Robinson, Francis (1993). "Technology and Religious Change: Islam and the Impact of Print.” Modern Asian Studies, 27: 229-251.

Rodinson, Maxime (1987). Europe and the Mystique of Islam, translated by Roger Veinus. Seattle: University of Washington Press; original French edition, 1980.

Sadeq, AbulHasan Muhammad (1990). Economic Development in Islam. Petaling Jaya, Malaysia: Pelanduk Publications.

Sayigh, Yusif A. (1958). "Toward a Theory of Entrepreneurship for the Arab East." Explorations in Entrepreneurial History, 10: 123-27.

Schumpeter, Joseph A. (1934). The Theory of Economic Development: An Inquiry into Profits, Capital, Credit, Interest, and the Business Cycle, translated by Redvers Opie. Cambridge, Mass.: Harvard University Press. 
Siddiqi, Muhammad Nejatullah (1979). The Economic Enterprise in Islam, $2^{\text {nd }}$ ed. Lahore: Islamic Publications.

Singerman, Diane (1995). Avenues of Participation: Family, Politics, and Networks in Urban Quarters of Cairo. Princeton: Princeton University Press.

Steinberg, Guido (2005). "The Wahhabi Ulama and the Saudi State: 1745 to the Present." In Saudi Arabia in the Balance: Political Economy, Society, Foreign Affairs, edited by Paul Aarts and Gerd Nonneman, pp. 11-34. Washington Square, New York: New York University Press.

Talbi, Mohammed (1960). “Les Bida'.” Studia Islamica 12: 43-77.

Turner, Bryan S. (1974). Weber and Islam: A Critical Study. London: Routledge \& Kegan Paul.

Udovitch, Abraham L. (1970). Partnership and Profit in Medieval Islam. Princeton: Princeton University Press.

Veinstein, Gilles (1999). "Commercial Relations between India and the Ottoman Empire (Late Fifteenth to Late Eighteenth Centuries): A Few Notes and Hypotheses," translated by Cyprian P. Blamires. In Merchants, Companies and Trade: Europe and Asia in the Early Modern Era, edited by Sushil Chaudhury and Michel Morineau, pp. 95-115. Cambridge: Cambridge University Press.

Weber, Max (1978). Economy and Society, 2 volumes, edited by Guenther Roth and Claus Wittich. Berkeley: University of California Press; original German edition, 1956.

Wehr, Hans (1980). A Dictionary of Modern Written Arabic. Beirut: Librarie du Liban.

Wood, Alfred C. (1935). A History of the Levant Company. London: Oxford University Press.

Zilfi, Medeline C. (1988). The Politics of Piety: The Ottoman Ulema in the Postclassical Age (1600-1800). Minneapolis: Bibliotheca Islamica. 